\title{
The Caddo Ceramics from Three Sites on Hawkins Creek in the Sabine River Basin, Gregg County, Texas
}

Timothy K. Perttula

Heritage Research Center, Stephen F. Austin State University

Follow this and additional works at: https://scholarworks.sfasu.edu/ita

Part of the American Material Culture Commons, Archaeological Anthropology Commons, Environmental Studies Commons, Other American Studies Commons, Other Arts and Humanities Commons, Other History of Art, Architecture, and Archaeology Commons, and the United States History Commons

Tell us how this article helped you.

This Article is brought to you for free and open access by the Center for Regional Heritage Research at SFA ScholarWorks. It has been accepted for inclusion in Index of Texas Archaeology: Open Access Gray Literature from the Lone Star State by an authorized editor of SFA ScholarWorks. For more information, please contact cdsscholarworks@sfasu.edu. 


\section{The Caddo Ceramics from Three Sites on Hawkins Creek in the Sabine River Basin, Gregg County, Texas}

\section{Creative Commons License}

\section{(c) (1) (8)}

This work is licensed under a Creative Commons Attribution-NonCommercial 4.0 International License 


\title{
The Caddo Ceramics from Three Sites on Hawkins Creek in the Sabine River Basin, Gregg County, Texas
}

\author{
Timothy K. Perttula
}

\section{INTRODUCTION}

Buddy Jones collected ceramic sherds from Caddo sites across the mid-Sabine River basin, in Gregg, Harrison, and Rusk counties, in the 1950s and 1960s. With only a few exceptions, however, did Jones complete analyses or publications on his collecting activities (see Jones 1957,1968), and in most cases his general collections have not been fully inventoried or analyzed. In an attempt to remedy that, and in the process gather important information on the technological and stylistic character of Caddo ceramics found in Caddo settlements in the mid-Sabine River basin, this article discusses the ancestral Caddo ceramic assemblages from three sites in the Hawkins Creek drainage in central Gregg County, Texas (Figure 1). Hawkins Creek is a small and southern-flowing tributary to the river.

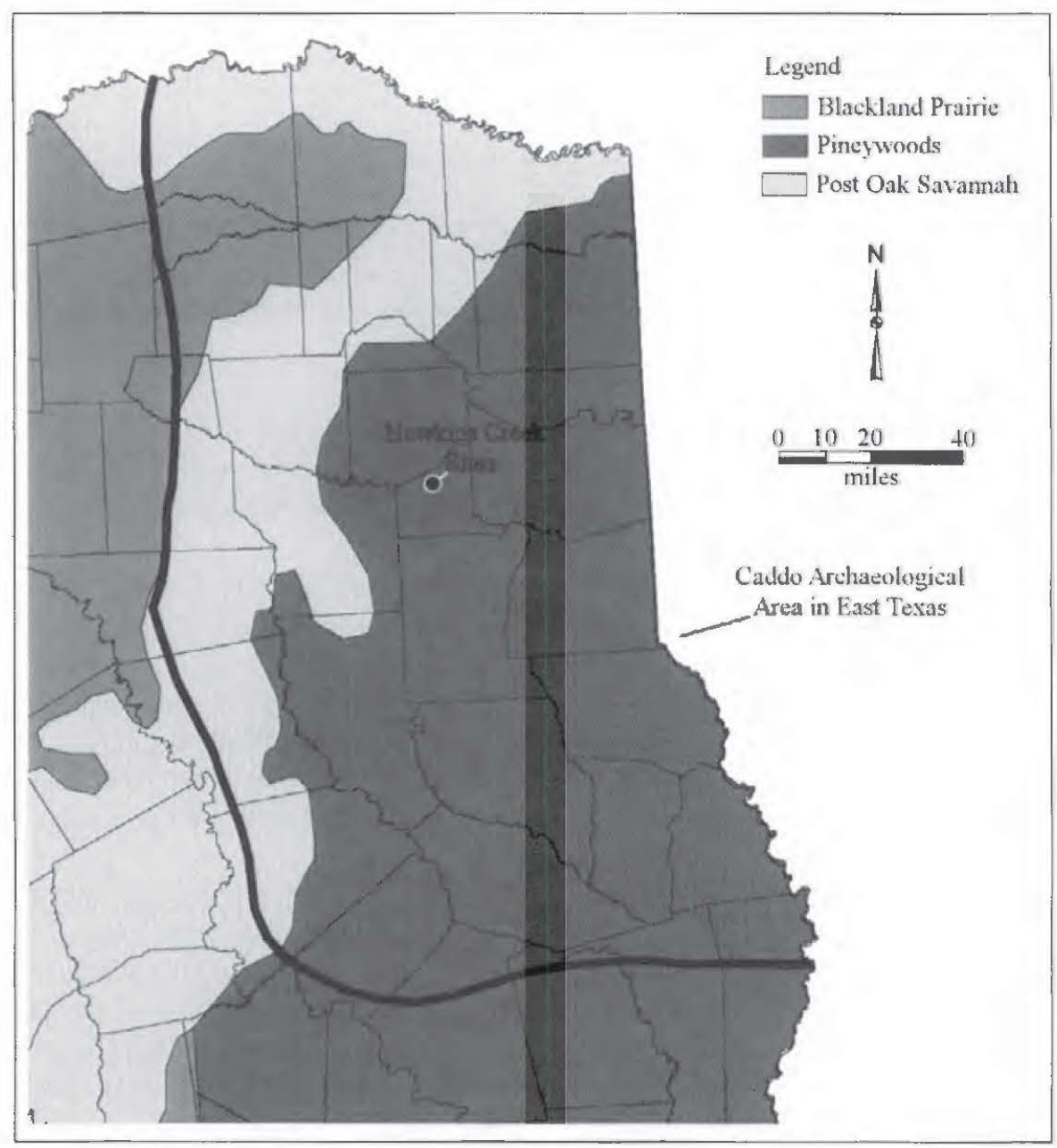

Figure 1. Location of the Hawkins Creek sites in Gregg County in East Texas. Figure prepared by Lance Trask. 


\section{GROUP'S PLACE SITE (GC'-77)}

There are 199 ceramic sherds from the Group's Place site, 132 plain sherds, 52 utility ware sherds, and 15 fine ware sherds (Table 1). The plain to decorated sherd ratio (P/DR) is 1.97. The sherds are from hoth grog-tempered $(67 \%)$ and bonc-tempered (33\%) vessels.

Table 1. Ceramic sherds from the Group's Place site.

\begin{tabular}{lcccc}
\hline Ware & Rim & Body & Base & N \\
\hline Plain ware & 7 & 110 & 15 & 132 \\
Utility ware & & & & \\
Brushed & 1 & 11 & - & 12 \\
Brushed-Incised & - & 5 & - & 5 \\
Incised & 1 & 11 & - & 12 \\
Incised-Punctated & 1 & 3 & - & 4 \\
Punctated & 1 & 18 & - & 19 \\
Fine ware & 3 & 12 & - & 199 \\
Engraved & 14 & 170 & 15 & \\
\hline Totals & & &
\end{tabular}

The most common utility wares have punctations (see Table 1), including sherds with rows of fingernail punctates $(n=1)$, tool punctates $(n=11)$, linear tool punctates $(n=4)$, and rows of circular punctates $(n=2)$. The one rim, probably from a Washington Square Paneled vessel (see Hart 1982; Perttula et al. 2010), has a row of diagonal tool punctates under the vessel lip.

Sherds with brushed and brushed-incised decorative elements comprise $32 \%$ of all the utility wares, and $25 \%$ of the decorated sherds from the Group's Place site (see Table 1). The one rim has horizontal brushing marks, while the body sherds have parallel brushed and/or incised marks and lines on the body of jars.

Incised sherds are common in the Group's Place utility wares (see Table 1). The one rim has diagonal incised lincs. The body sherds have parallel $(n=7)$, cross-hatched $(n=2)$, diagonal $(n=1)$, and straight $(n=1)$ lines.

The first incised-punctated rim sherd from the site has a band of diagonal tool punctates under the lip and above a single horizontal incised line. This rim may also be from a Washington Square Paneled vessel. Two body sherds have incised triangles filled with tool punctates, while a third incised-punctated body sherd has curvilinear and semi-circular incised elements or panels filled with tool punctates (Figure $2 \mathrm{~b}-\mathrm{c}$ ).

The engraved fine wares at the Group's Place site account for $22.4 \%$ of the decorated sherds in the assemblage (see Table 1), indicating ready access to the use of fine wares by the Caddo peoples living there. All three rim sherds have horizontal engraved lines, and at least one is from a compound bowl with horizontal engraved lines on the rim's upper panel. One sherd from the neck and upper body of a collared bottle has a single horizontal engraved line on the upper body. Other body sherds have a straight line $(n=3)$, diagonal opposed engraved lines ( $n=3$, Figure $3 b$ ), vertical lines $(n=2)$, and parallel lines $(n=1)$. Another sherd from a carinated howl has horizontal and diagonal opposed engraved lines, while the last engraved sherd from the sherd has a horizontal engraved line and narrow near-vertical open or diagonal hatched panels or ladders (Figure $3 \mathrm{c}$ ). 


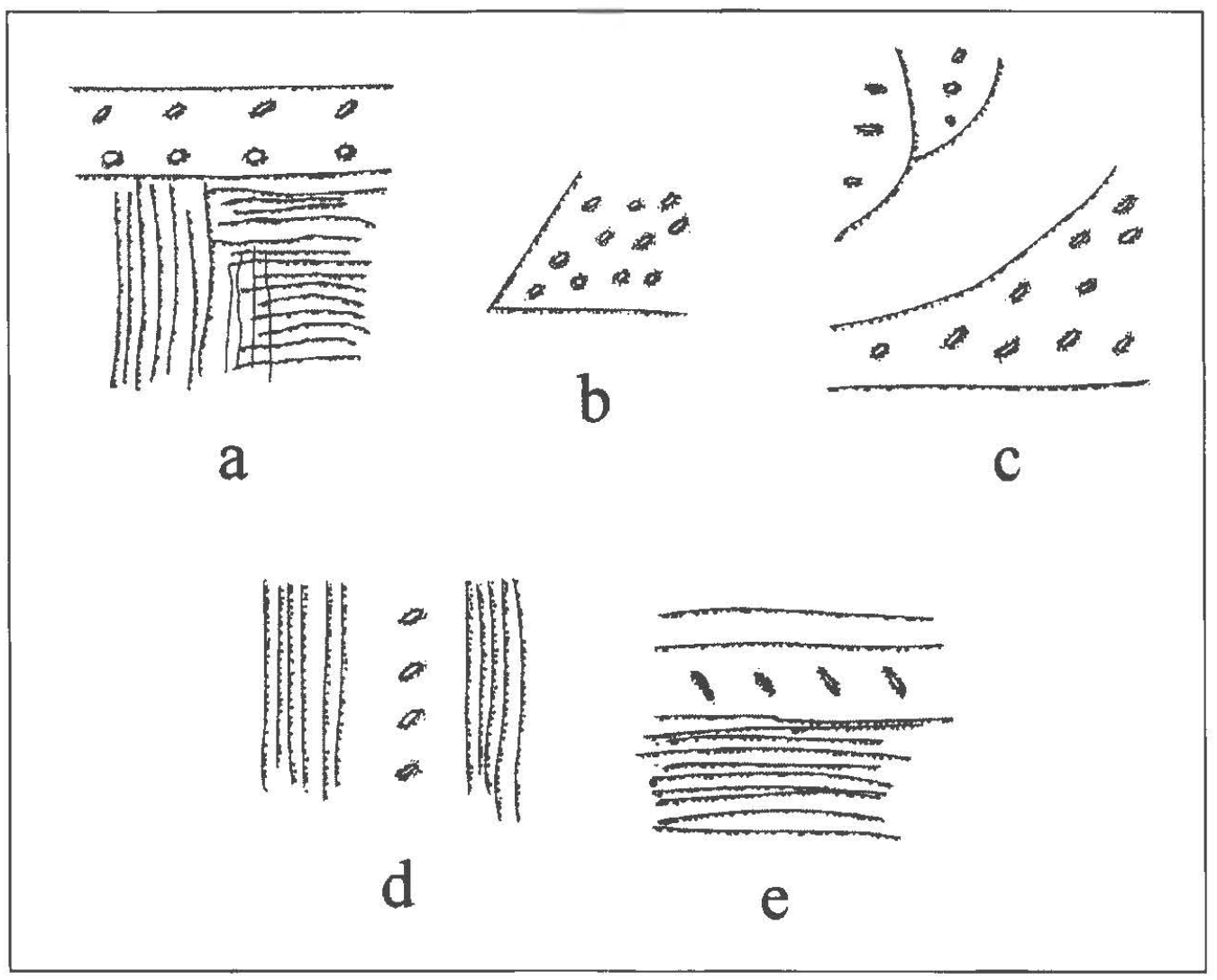

Figure 2. Hawkins Creek sites utility wares: a, incised-punctated-brushed element, GC-90; b-c, incised-punctated elements. GC-77; d, parallel brushed-tool punctated row, GC-78; e, incised-puncrated-brushed element, GC-78.

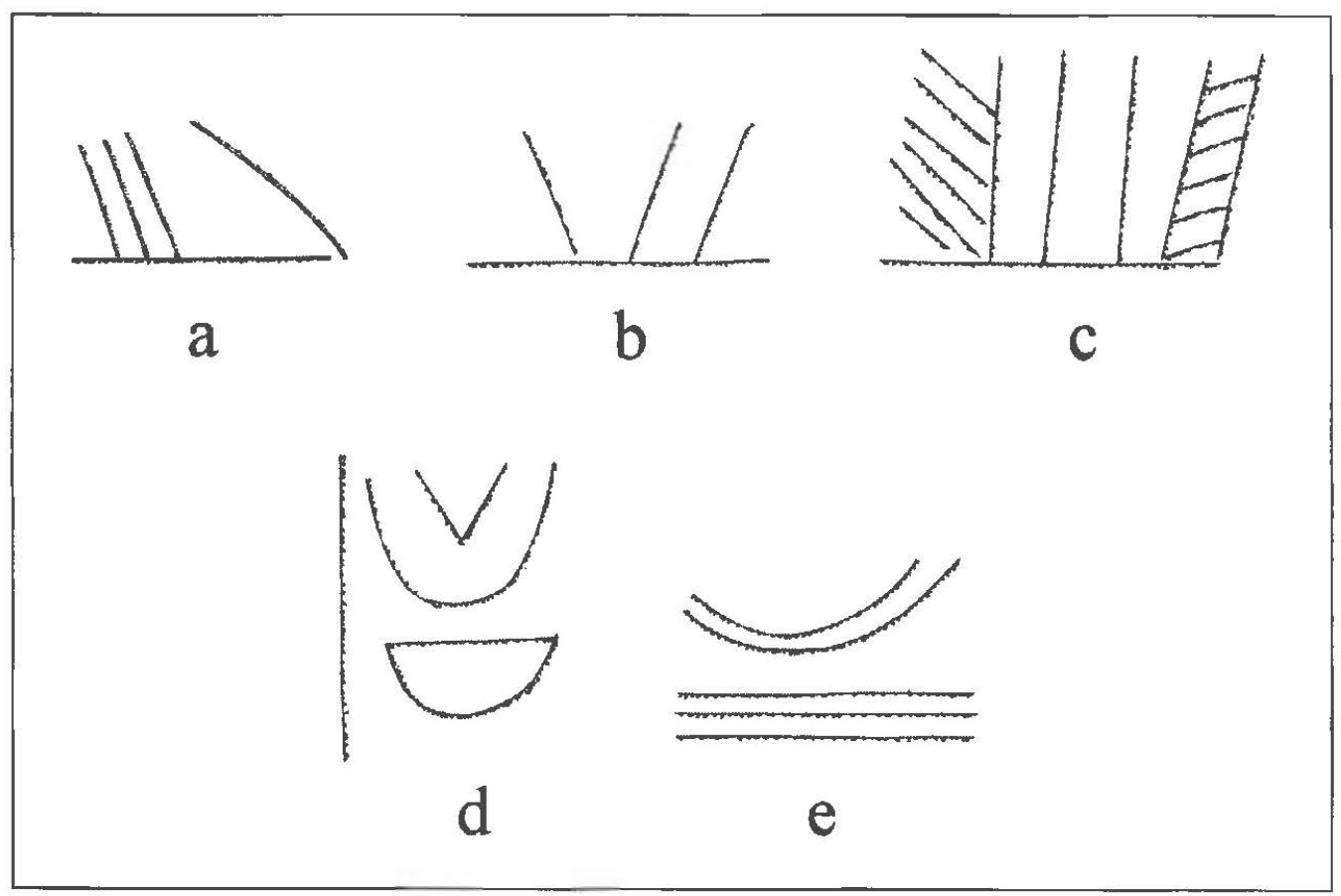

Figure 3. Hawkins Creek sites fine wares: a, engraved carinated bowl element, GC-90; b-c, engraved elements, GC-77; d-e, engraved elements, GC-90. 


\section{GC-78}

There is only a small sample of ceramic sherds from GC-78, including 21 plain sherds. 26 utility ware sherds, and two line ware sherds (Table 2 ). The P/DR is 0.75 . The sherds are from vessels tempered with grog $(88 \%)$ and bone $(12 \%)$

Table 2. Ceramic sherds from (YC-78.

Ware

Plain ware

\section{Utility ware}

Brushed

Brushed-Incised

Brushed-Punctated

Incised

Incised-Punctated

Incised-Punctated-Brushed

Pinched

Fine ware

Engraved-Punctated

Red-slipped

Totals

\begin{tabular}{cc}
\hline Rim & Body \\
\hline- & 18 \\
& \\
- & 11 \\
- & 4 \\
- & 1 \\
1 & 3 \\
1 & 2 \\
- & 1 \\
- & 2
\end{tabular}

\begin{tabular}{c}
1 \\
- \\
1 \\
\hline $2 \quad 44$ \\
\hline
\end{tabular}

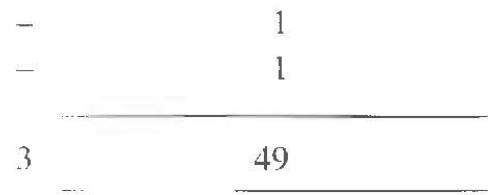

Among the utility wares, the most common are sherds from vessels with brushed or brushed-incised bodies, likely decorated with vertical brushing and/or incised marks and lines that extend from the rim-body juncture to near the vessel base. The brushed and brushed-incised sherds account for $58 \%$ of the utility wares. and $54 \%$ of all the decorated sherds from GC-78 (see Table 2). Incised utility wares include a single rim with diagonal incised lines, probably from a Maydelle Incised vessel, as well as body sherds with cross-hatehed or parallel incised lines.

There are two sherds with brushed-punctated and incised-punctated-brushed decorations (see Table 2). The first may be from a Pease Brushed-Incised jar: it has vertical open panels with a row of tool punctations down their center, with the pancls flanked by vertical brushing marks (see Figure $2 \mathrm{~d}$ ). The second sherd has horizontal incised lines below the rim-body juncture, followed by a row of linear tool punctations, and then by horizontal brushing marks ( $\mathrm{sec}$ Figure $2 \mathrm{e}$ ).

The two pinched body sherds are likely from Killough Pinched jars. One sherd has curvilinear rows of pinching while the other has parallel pinched rows.

The incised-punctated rim sherd has at least two rims of tool punctates between horizontal incised lines. One of the body sherds has a similar decorative element, except there are multiple incised lines between the bands of punctates. The other incised-punctated body sherd has an incised triangle filled with tool punctates; it is from a Maydelle Incised jar.

One of the fine ware sherds from GC-78 (see Table 2) is a body sherd with a red slip on both interior and exterior vessel surfaces. The other is a rim, likely from a carinated bowl, with a narrow horizontal 
engraved band under the lip filled with diagonal tool punctates. This decorative element is consistent with the Washington Square Paneled type (see Hart 1982). A vessel of this type has been identified from Burial 2 (Vessel No. 7) at 4lGG50 on Hawkins Creek (Perttula and Nelson 2013:Figures 27 and 28).

\section{LOCKS' (GC-90)}

The Locks' site ceramic sherd assemblage includes 96 sherds, 22 plain ware, 64 utility ware, and 10 fine ware (Table 3). The P/DR is 0.30 . Almost $40 \%$ of the sherds are from bone-tenpered vessels, and the remainder are grog-tempered.

Table 3. Ceramic sherds from Locks' (GC-90).

\begin{tabular}{lcccc}
\hline Ware & Rim & Body & Base & N \\
\hline Plain ware & - & 20 & 2 & 22 \\
Utility ware & & & & \\
Brushed & - & 30 & - & 30 \\
Brushed-Incised & - & 14 & - & 14 \\
Brushed-Punctated & 1 & 6 & - & 7 \\
Incised & $\mathrm{f}$ & 6 & - & 7 \\
Incised-Punctated & 2 & - & - & 2 \\
Incised-Punctated-Brushed & 1 & 1 & - & 2 \\
Punctated & - & 2 & - & 2 \\
Fine ware & & & & 10 \\
Engraved & $\mathrm{t}$ & 9 & - & 96 \\
\hline Totals & 6 & 88 & 2 & \\
\hline
\end{tabular}

The utility wares from the Locks' site are dominated by sherds from vessels with brushed rims and bodies. These comprise $83 \%$ of the utility wares and $72 \%$ of all the decorated sherds from the site (see Table 3 ). The one brushed-punctated rim sherd has a row of tool punctates under the vessel lip, as well as horizontal brushing marks. A lower rim and body sherd from a probable Maydelle Incised jar has diagonal incised lines on the rim, as well as a tool punctated row at the rim-body juncture, and diagonal brushing marks on the vessel body. Body sherds have parallel brushing marks $(n=30)$ and parallel or opposed brushed-incised marks and lines $(n=14)$. The brushed-punctated body sherds include one with a row of tool punctates above diagonal brushing marks, another two sherds with parallel brushing marks adjacent to a tool punctated row, and three Pease Brushed-Incised sherds with tool punctated rows pushed through parallel brushing marks. The one incised-punctated-brushed body sherd has an incised panel filled with two rows of tool punctates, with the panel above vertical and horizontal opposed brushing marks (see Figure 2a).

The incised sherds include a Maydelle lncised rim with diagonal opposed lines and six body sherds with parallel incised lines. Both incised-punetated sherds are rims (see Table 3). Both have a row of tool punctates under the vessel lip and above horizontal incised lines.

Fine wares account for only $13.5 \%$ of the decorated sherds from the Locks' site (see Table 3 ). The engraved rim has horizontal engraved lines on it. The body sherds are likely all from carinated bowls. These include sherds ( $\mathrm{l}=7$ ) with simple geometric elements: two sherds have parallel lines, three body sherds have 
a single curvilinear engraved line, and another has a straight engraved line with an open triangle element pendant from the line. One body sherd has sets of diagonal lines attached to a straight line (see Figure 3a); this may be part of a slanted scroll motif. The other engraved body sherds have curvilinear elements: the first has a panel with ovals, semi-circles, and open triangles (see Figure 3d), while the other has a set of two curvilinear lines adjacent to a set of several parallel engraved lines (see Figure 3e).

\section{SUMMARY AND CONCLUSIONS}

Between the three Hawkins Creek sites there are 169 decorated sherds. Fine wares comprise only between $7.2-22.4 \%$ of the decorated sherds, and the assemblages are dominated by utility wares (Table 4). In the case of the Group's Place site (GC-77), the utility wares have primarily punctated, incised, and incised-punctated $(52.3 \%$ of all the decorated sherds) elements, while the utility wares at GC-78 and Locks' (GC-90) have primarily brushed decorative elements, or brushing in combination with other (i.e., incised, punctated, and incised-punctated) decorative methods. At the latter two sites, sherds with brushing marks comprise $60.8-71.6 \%$ of all the decorated sherds in their assemblages (Table 4); incised, punctated, and incised-punctated sherds represent only $14.9-25.0 \%$ of the sherds from these two sites. Sherds with pinching are only present at GC-78.

Table 4. Decorated sherd comparisons.

\begin{tabular}{lccc}
\hline Decorative Method & GC-77 & GC-78 & GC-90 \\
\hline Brushed & $17.9^{*}$ & 39.3 & 40.5 \\
Brushed-Incised & 7.5 & 14.3 & 18.9 \\
Brushed-Punctated & - & 3.6 & 9.5 \\
Incised & 17.9 & 14.3 & 9.5 \\
Incised-Punctated & 6.0 & 10.7 & 2.7 \\
Incised-Punctated-Brushed & - & 3.6 & 2.7 \\
Pinched & - & 7.1 & - \\
Punctated & 28.4 & - & 2.7 \\
& & - & 13.5 \\
Engraved & 22.4 & 3.6 & - \\
Engraved-Punctated & - & 3.6 & - \\
Red-slipped & - & 28 & 74 \\
\hline Totals & 67 & & \\
\hline
\end{tabular}

*Percentage

Identified ceramic types in these sherd assemblages include Washington Square Paneled (GC-77 and GC-78), Maydelle Incised (GC-78 and GC-90), Pease Brushed-Incised (GC-78 and GC-90), and Killough Pinched (GC-78). In general, the Washington Square Paneled vessel sherds are indicative of Middle Caddo period (ca. A.D. 1200-1450) components, while the other identified types can be expected in both Middle and Late Caddo components in the mid-Sabine River basin.

Another indication of the age of the ceramics on these Caddo components is the proportions of brushed sherds in broadly contemporaneous mid-Sabine River Harrison and Rusk County sites, which range from 26-67\% (Heartfield, Price, and Greene, Inc. 1988; Gadus et al. 2006; Dockall et al. 2008; Dockall and Fields 2011; Perttula and Nelson 2013). The site with the lowest proportion of brushed pottery in the decorated sherd assemblages is 41 HS 846 (Gadus et al. 2006), which has Bonham arrow points and two calibrated 
radiocarbon dates that range from A.D. 1280-1420 at two sigma (Gadus et al. 2006). At 41 GG5, 28\% of the sherds from burial fill and surface collections have brushing marks, while at the Joe Smith site (41GG50), $40 \%$ of the decorated sherds are brushed or brushed-punctated. At 41 HS74, 29\% of the decorated sherds are brushcd; the site has an uncalibrated radiocarbon date of A.D. $1320 \pm 240$ (Hcartfield. Price, and Greene, Inc. 1988). These dates probably serve as a good approximation of the age range of the settlements and small cemetcries at the Group's Place site, from the late $13^{\text {th }}$ century to the mid- $14^{\text {th }}$ century. The occupation at GC-78 may date a few generations later, perhaps to the early $15^{\text {th }}$ century. The site with the highest proportion of brushed sherds is $41 \mathrm{HS} 573$ (Gadus et al. 2006). The sherd assemblage from the site (67\% brushed) is associated with a calibrated 2 sigma age range of A.D. 1450-1660 (Gadus et al. 2006). The Locks' (GC-90) site may date to sometime in this Late Caddo time range. The engraved finc wares at this site do not resemble Late Caddo, Titus phase styles such as have been documented at a number of sites in the Pine Tree Mound community (see Fields and Gadus 2012).

Two of the three Hawkins Creek sites have ceramic assemblages where burned bone was an important temper used in vessel manufacture (Table 5). This is consistent with the aforementioned broadly contemporaneous Caddo sites in the mid-Sabine River basin. This includes sherds from 41HS74 (20\% with bone temper, Heartfield, Price, and Greene, Inc. 1988); 41 HS.573 (29\% with bone temper and $21 \%$ with grog and bone, Gadus et al. 2006); 4 I HS574 (19.5\% with bonc temper and $16.5 \%$ with grog and bone, Gadus et al. 2006); 41 HS 588 (3.4\% with bone temper and 35\% with grog and bone. Dockall et al. 2008); 41 HS 844 (11\% with bone temper and 25\% with grog and bone, Gadus et al. 2006); 41 HS846 (12\% with bone temper and $16 \%$ with grog and bone); and 41 RK 557 (29\% with bone temper and $22 \%$ with grog and bone, Dockall and Fields 2011).

Table 5. Use of bone temper in Hawkins Creek Caddo ceramics.

\begin{tabular}{lccc}
\hline Ware & GC-77 & GC-78 & GC-90 \\
\hline Plain & $31.8^{*}$ & 9.5 & 50.0 \\
Utility & 38.5 & 15.4 & 35.9 \\
Fine & 20.0 & - & 40.0 \\
\hline Total Percentage & 32.7 & 12.4 & 39.6 \\
\hline
\end{tabular}

*Percentage

In general, sites in the region with considerable use of burned bone temper also have high proportions of brushed sherds. This is not the case at site GC-78, however (see Table 5), even though the proportions of brushed sherds in the assemblage is considerable (see Table 4), suggesting the existence of different ceramic manufacturing practices among the Caddo potters that lived there when compared to the potters at the Group's Place and Locks' sites.

In conclusion, these three sites on Hawkins Creck are part of a community of ancestral Caddo peoples that lived along the Sabine River and its tributaries, and they were contemporaneous with better known Middle and Late Caddo sites in the Pine Tree Mound community defined by Fields and Gadus (2012:Figure 9-10) some $25-40 \mathrm{~km}$ downstream in the Sabine River basin - which was established in the $1300 \mathrm{~s}$. However, the differences in the ceramics between the two areas suggest that the Hawkins Creek sites were not part of that community. 


\section{ACKNOWLEDGMENTS}

I very much appreciate the assistance provided by Patti Haskins of the Gregg County Historical Museum in accessing these sherd assemblages in the Buddy Jones collection. Lance Trask prepared the sherd drawings.

\section{RFFERENCES CITED}

Dockall, J. E. and R. C. Fields

2011 National Register Testing of Three Sites in the Sabine Mine's South Hallsville No. I Mine-Rusk Permit, Rusk County, Texas. Report of Investigations No. 162. Prewitt and Associates, Inc., Austin.

Dockall, J., S. Katauskas, and R. Fields

2008 Natinnal Register Testing of Four Sites in the Sabine Mine's Area M, Harrison Count, Texas. Reports of Investigations No. 157. Prewitt and Associates, Inc., Austin.

Fields, R. C. and E. F. Gadus (editors)

2012 Archeology of the Nadaco Caddo: The View from the Pine Tree Mound Site (411/S15), Harrison Commy, Texas. 2 Vols. Reports of Investigations No. 164. Prewitt and Associates, Inc., Austin.

Gadus, E. F., R. C. Ficlds, J. K. McWilliams, J. Dockall, and M. C. Wilder

20006 National Register Testing of Seven Prehistoric Sites in the Sabine Mine's Area Q. Harrison Coumt: Texas. Reports of Investigations No. 147. Prewitt and Associates, Inc., Austin.

Hart, J. P.

1982 An Analysis of the Aboriginal Ceramics from the Washington Square Mound Site, Nacogdoches County. Texas. Master's thesis, Department of Anthropology, Northeast Louisiana University, Monroe.

Heartield, Price, and Greenc, Inc.

1988 Data Recovery at 41HS74, Harrison Count, Texas. Heartfield. Price. and Greene. Inc.. Monroe.

Jones, B. C.

1957 The Grace Creek Sites, Gregg County. Texas. Bulletin of the Texas Archeological Soriety 28:198-231

1968 The Kinsloe Focus: A Study of Seven Historic Caddoan Sites in Northeast Texas. Matster's thesis, De partment of Anthropology, University of Oklahoma, Norman.

Perttula, T. K. and B. Nelson

2013 Two Middle Caddo Period Habitation Sites and Cemeteries in the Sabine River Basin, Gregg County, Texas. Special Publication No. 27. Friends of Northeast Texas Archaeology. Pittsburg and Austin.

Perttula, T. K., M. Walters, B. Nelson, B. Gonzalez, and R. Cast, with a contribution by R. G. Franciscus

2010) Documentation of Associated and Unassociated Caddo Funerary Objects in the Stephen F. Austin State University Collections, Nacogdoches, Texas. Stephen F. Austin State University Press, Nacogdoches. 